\title{
Library Research in North Carolina
}

- Ilene Nelson, Column Editor

Abstracts of master's papers submitted by students enrolled in the School of Information and Library Science at the University of North Carolina-Chapel Hill in fulfillment of their degree requirements were published in this column for the first time in the Winter 1990 issue of North Carolina Libraries. The response from readers was sufficient to prompt this second review of research being done by the students at one of our state's library schools. The papers themselves are available through interlibrary loan from the Library School Library at UNC.

According to figures reported in the Digest of Education Statistics 1991, there are more than 90,000 library/media centers in public and private schools in the United States. Compare this with the approximately 15,000 public, 9,000 special, and 4,500 academic libraries. By virtue of their numbers alone, school library/media centers merit study. The following three papers describe research involving this sector.

Mark D. Blaisdell-Buck. Curriculum Integration Between Media Center and Classroom: Teacher Attitudes and a Tool for Implementation. A Master's paper for the M.S. in L.S. degree. July 1990. 46 pages. Advisor: Ray Carpenter

The three major objectives of the study are: (1) to facilitate the creation of lesson plans for classroom teachers and school library media specialists, (2) to integrate the curriculum of the classroom with the media center, and (3) to initiate a database to contain the lesson plans created using a tool designed from survey data obtained and a review of the literature. A survey of teachers in the Charlotte-Mecklenburg Public Schools was conducted to determine the classroom teachers' willingness to participate in a program involving curriculum integration, and their perceptions of media center use. The primary variables analyzed were (1) perceptions of media use, (2) administrative support of the media center, (3) teacher involvement with media center activities, (4) disposition toward curriculum integration, and (5) demographic variables. The findings were used to develop a tool which meets the study's three major objectives.

Maureen D. Jones. A School Library Media Program: Using Information Power to Design a School Library Media Program for an Independent High School. A Master's paper for the M.S. in L.S. degree. December 1990. 62 pages. Advisor: Barbara B. Moran

This paper has consolidated the recommendations of the national, state, county, district and school level guidelines to create a quality school library media program. The purpose of this project was to fulfill the need for a written media program in a small, independent high school. The problem addressed the lack of a media program at the high school, and the need to satisfy that requirement based on the recommendations of the visiting accreditation team for the Southern Association of Colleges and Schools (SACS). The result of this project is a school library media program which has been designed for the specific needs and limitations of a small, college-preparatory high school, acknowledging and encompassing the range of recommendations from all levels of the education network.

Maxine Wise. The Use of Modified Pathfinders to Facilitate Bibliographic Instruction in a Middle School. A Master's paper for the M.S. in L.S. degree. July 1990. 38 pages. Advisor: Evelyn H. Daniel This paper addresses bibliographic instruction at the secondary level. Several issues are identified and analyzed which concern the success of bibliographic instruction at the secondary level as perceived by professional librarians. In addition to analyzing the salient issues relative to this topic, a method of bibliographic instruction is sought which would provide a greater chance for success. A pathfinder model which has strong potential is identified. Modifications to the model are proposed which would create a teaching tool more appropriate for secondary school students. The development, rationale, and description of this tool are the substance of this paper.

Papers written by Melissa Lamont and Mary McNabb explore aspects of the distribution of government information, with particular emphasis on the impact of electronic formats. Stuart Basefsky, a documents librarian at Duke University, contributed an essay also addressing the ramifications of electronic distribution of government information to the December 12,1991, issue of the Christian Science Monitor.

Melissa Lamont. Access to Federal Government Publication: Old Problems and New Technologies. A Master's paper for the M.S. in L.S. degree. July 1990. 28 pages. Advisor: Ridley R. Kessler, Jr. This study reviews the controversy over the distribution of federal government publications, particularly electronic publications. The issues of privatization, commercialization and copyright of government documents are discussed. Included are several proposals for the alteration or enhancement of the Depository Library program.

Mary C. McNabb. The Depository Library Council, the GPO, and the Struggle Over the Inclusion of Electronic Formats in the Depository Library Program. A Master's paper for the M.S. in L.S. degree. July 1990. 70 pages. Advisor: Ridley R. Kessler, Jr.

This study traces the Depository Library Council's recommendations which focus upon government information and publications in electronic format. The purpose of this study of the Council's recommendations is to determine the influence of the recommendations on the GPO's policies and practices.

The purpose of the Depository Library Council to the Public Printer is to provide advice on matters dealing with the Depository Library Program. The submittal of recommendations to the Public Printer is the Council's 
formal method of advisement. The correlation between Council recommendations and the resulting actions of the GPO is evidence that the Council has visibly shaped the policies and practices of the GPO dealing with the inclusion of electronic formats in the Depository Library Program.

The balanced development of the library's collection is always a challenge. Patricia Hattler's study of non-fiction needs and interests along with the more specialized investigations by Dianitia Hutcheson and Alisa Whitt offer practical guidance.

Patricia Hattler. Determining Information Needs and Interests: A Content Analysis of a Public Library's Nonfiction Reserve List. A Master's paper for the M.S. in L.S. degree. December 1990. 34 pages. Advisor: Evelyn H. Daniel

This study uses content analysis of reserve lists from a large branch of a county library system to determine reading interests and the effects of best sellers on demand. Nonfiction reserve lists for a four-month period were analyzed and categories were established. Best sellers accounted for an average of approximately 3\% of titles and $30 \%$ of requests. Categories with the highest numbers of individual titles were Biography ( $8.3 \%)$, Psychology (7.5\%), and Personal Success in Business $(7.3 \%)$. Categories with the highest number of requests were Economics and Business (12.6\%), Biography (10\%), and History/Political Science/International Relations $(7.8 \%)$. Not all best sellers were popular, and many requests were for older titles. The use of content analysis is recommended to collection development staff as an aid to determining reader interests and evaluating existing collections and book buying practices.

Dianitia Hutcheson. Clergy-Recommended Religious Books for Public Libraries. A Master's paper for the M.S. in L.S. degree. November 1990. 55 pages. Advisor: Robert N. Broadus

This study describes a survey of selected clergy in Raleigh, Durham, Greensboro, and Winston-Salem, North Carolina. The survey was conducted to obtain a list of books which clergy people recommend be included in a public library collection.

Twenty-four Southern Baptist, Roman Catholic, and Episcopal clergy people made 278 recommendations of 212 titles. The list was examined for duplicate recommendations and original publication years. It was compared to several bibliographies and to the holdings of the public library in one of the survey cities. The list was classified by subject using the Dewey Decimal system and observations were made. Finally the list was examined by denomination.

Alisa J. Whitt. The Information Needs of Lesbians and Bisexual Women. A Master's paper for the M.S. in L.S. degree. July 1990. 68 pages. Advisor: Elfreda A. Chatman

This study describes a questionnaire survey of 141 lesbians and bisexual women in a metropolitan area of North Carolina. The survey was conducted to determine the information needs of these women and to explore the relationship between the process of homosexual identity acceptance and changing information needs. In addition to assessing library usage and library satisfaction, this study also examined information needs as they exist within the situational contexts of these women's lives. Results of the survey indicated that during the initial stages of coming to terms with a lesbian or bisexual self, information needs concern identity acceptance and locating other lesbians/bisexuals. At this point, individuals are ignorant about homosexuality and the gay subculture; therefore, mainstream sources of information offer the only known alternative for locating lesbian-related information. The library is used heavily at this stage. During the later stages of identity acceptance, information needs become more specific and information sources are consulted with more discrimination. The library is relied upon less during these later stages because women have located the gay subculture and prefer it for information. These women constitute an information rich population, and many of them are regular or frequent library users. Overall, satisfaction with the library's collection of lesbian materials is low; respondents consistently report that collections are meager and dated. Furthermore, respondents feel that librarians are unable to serve adequately this population due to their ignorance or homophobia. In light of respondents' suggestions, several recommendations are made for improvement of the library's services to this population.

\section{The wtore Things Ehange ...}

The records of our local history ought to be preserved. And if the public library does not do the job, probably it will not be done. - North Carolina Libraries, March and May 1957, p. 63.

\section{Tired of making} "permanent loans?"

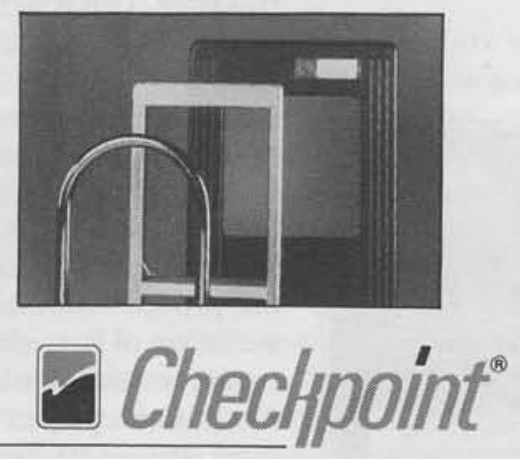

Tomorrow's Technology for Today's Libraries ${ }^{\mathrm{TM}}$

550 Grove Road • P.O. Box 188 - Thorofare, New Jersey 08086 (800) 257-5540 - TELEX: 84-5396 - FAX: (609) 848-0937

Wes Brewer, Sales Representative 2921 Welcome Drive Durham, North Carolina 27705 (919) 493-2161 